\title{
Ungdom, kriser og selvmordsatferd - med forskerens og Ibsens øyne
}

\author{
Ved Berit Grøholt
}

\section{En jente fikk ved en tilfeldighet vite at faren, som hun satte meget høyt, kanskje ikke var hennes egentlige far. Denne kunnskapen var også ukjent for faren, og hele grunnlaget for familiens harmoni ble forrykket: Familien var i krise. Jenta} var opptatt av å vise at hun var glad i faren sin uansett, mens han tvilte på datterens varme følelser og ønsket bevis på at hennes kjaerlighet til ham var ekte. "Hadde jeg bedt henne ofre livet for meg" sier han, "så ville vi nok fått høre--". Jenta overhører denne uttalelsen, og skyter seg.

\section{Er én krise nok til å utløse selvmord?}

De fleste vil kjenne denne historien igjen fra Ibsens Vildanden. En akutt krise fører til et impulsivt selvmord, og understreker at unge mennesker kan ta sitt eget liv helt uten forvarsel. M en la oss al likevel se hva Ibsen gir oss av informasjon om H edvigs situasjon før krisen, lenge før han eller noen andre hadde forskningbasert kunnskap å støtte seg til. I denne artikkelen vil vi se hva Ibsen kan ha hatt i tankene, og sammenlikne med ny forskning, først og fremst fra $\mathrm{N}$ orge.

\section{F orholdet til andre mennesker}

De fleste av oss danner automatisk idéer om hva personer vi er knyttet til, opplever og sanser. D eres behov spiller som regel en rolle for våre valg, selv om vår innlevelse knapt noen gang er fullstendig. $N$ år det gjelder innlevelse, stiller $\mathrm{H}$ edvigs far $\mathrm{H}$ jalmar Ekdal svakere en $\mathrm{n}$ de fleste. Ibsen beskriver livsløgneren $\mathrm{H}$ jalmar Ekdal som et egosentrisk menneske, uten evne eller vilje til å sette seg inn i andre menneskers situasjon. $\AA$ bli sett realistisk av andre beskytter i en viss grad mot selvmord, kanskje fordi det er en viktig forutsetning for fortrolighet. $\mathrm{H}$ edvig med sine behov blir ikke sett av faren, og det gjør henne sårbar. M en $\mathrm{H}$ edvig er også beskyttet. $\mathrm{H}$ un blir sett av sin mor, og også av naboen og husvennen $\mathrm{dr}$. Relling, som fungerer som et talerør for I bsen. Forskning, også fra N orge, har vist at et fortrolig forhold, især til foreldre, er en av de sterkeste beskyttelser mot selvmordsatferd ( $G$ ould et al. 1996; G roholt et al. 2000).

På den annen side virker $\mathrm{H}$ edvig isolert i forhold til jevnaldrende venner. $\mathrm{H}$ un er svaksynt og går ikke på skolen, faren skal undervise henne hjemme når han får tid. H un er i en alder da tilknytning til familien normalt skal løsnes i forhold til tilknytning til jevnaldrende, og berede veien for et selvstendig voksenliv. M anglende kontakt med andre unge gjør $\mathrm{H}$ edvig sårbar når hun får problemer med de få personer hun kan støtte seg til. Vi vet fra forskning (G roholt et al. 2000) at det beskytter mot selvmordsforsøk å føle seg som en del av en ungdomsgruppe.

Ibsen viser oss også at $\mathrm{H}$ edvig har mye ansvar. H un hjel per faren med hans arbeid, og sin mor Gina hjelper hun med husholdningsregnskap. M oren deler sine voksne bekymringer med datteren, og mange vil si at Ibsen viser at $\mathrm{H}$ edvig er "parentifisert", det vil si at hun får for mye ansvar $i$ ung alder. M en ansvar som mestres godt, kan også være en beskyttelse mot senere kriser (G jærum et al. 1998). $\mathrm{H}$ edvig mestrer det daglige ansvaret, og samspillet mellom H edvig og $\mathrm{G}$ ina er fortrolig. M en det fører også til at H edvig lett føler ansvar og søker løsninger som en følge av det. I en krisepreget situasjon vil hun som barn vanskeligere skille melIom hva som er rimelige og urimelige Iøsninger. I skuespillet forsøker hun å løse farens problem ved å vise ham sin kjærlighet på en helt urimelig måte.

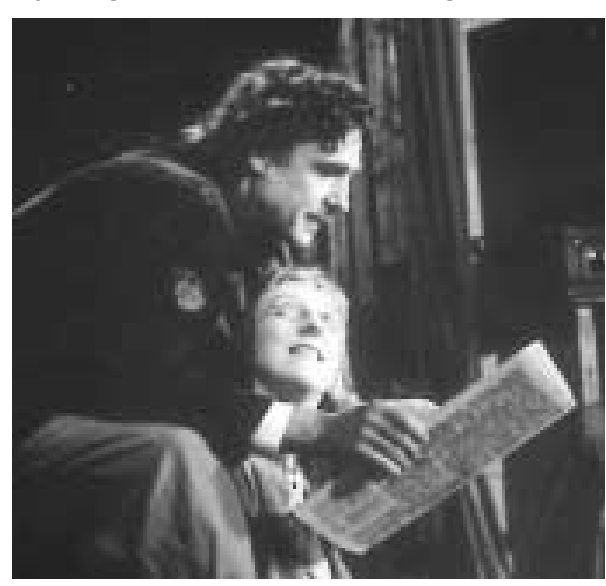

F ra N ationaltheaterets oppsetning av Vilanden 1996. I rollen som H edvig: Å got Senstad. Faren, H jalmar Ekdal spilles av Bjørn Skagestad.

A Itså har Ibsen beskrevet en spesiell sårbarh et hos H edvig, som samstemmer godt med det senere forskning har vist.

\section{Smitteeffekt}

$V i$ vet at unge er spesielt utsatt for "smitte" fra selvmordsatferd hos andre, spesielt innen sin egen familie ( $G$ røholt 1999). I bsen lar oss vite at både bestefaren og faren en gang har hatt tanker om å ta sitt eget liv. H edvig har ikke levd med selvmordstrusler, det ville gjort henne ekstra utsatt. $M$ en hun er i naborommet da faren sier at bestefar var feig da han ikke skjøt seg, slik han engang planla. Igjen har I bsen sett langt. Forherligelse av konkrete selvmordshandlinger øker risiko for smitteeffekt. A Itså har I bsen plassert enda en risikofaktor i Hedvigs omgivelser.

\section{P sykisk helse}

Den viktigste risikofaktor for selvmord er psykisk sykdom, ifølge rådende forskning (Schaffer et al. 1996). H edvig virker sunn nok, selv om hun er svaksynt og vet at hun før eller senere vil bli blind. M en Ibsen setter også et spørsmålstegn her. $\mathrm{H}$ an lar dr. Relling si han er redd $\mathrm{H}$ edvig kan gjøre seg selv noe. H un er "i en vanskelig alder, og kan finne på alt". M oren bekrefter at $\mathrm{H}$ edvig har forandret seg og er opptatt av katastrofer. $\mathrm{H}$ un "leker ildebrand" på kjøkkenet. I bsen mener kanskje at tenårene i seg selv representerer en psykisk krise. I så fall har han ikke forskningen med seg. $\mathrm{H}$ vis unge reagerer avvikende psykisk, skyldes det ikke ungdomsalderen i seg selv, men at de er overbelastet med problemer eller har en psykisk lidelse. U tsiktene for utviklingen av en slik lidelse er ikke stort annerledes for unge enn for eldre. $0 \mathrm{~m} \mathrm{H}$ edvig allikevel har en psykisk lidelse, vet vi ikke nok om. $M$ en de to voksne som ser henne best, moren og Relling, er iallfall bekymret for hennes psykiske balanse. Igjen har Ibsen satt fingeren på et hovedpunkt. 


\section{Selvmordsmetode}

I bsen lar et ladd gevær ligge på en hylle i familien Ekdals stue. Forskning fra U SA viser at tilgang på skytevåpen øker risikoen for selvmord. Selv om tilsvarende forskning ikke er utført i N orge, er skytevåpen årsak til en langt større andel av selvmord blant unge under 20 år hos oss enn i resten av Vest-Europa ( $G$ roholt et al. 1997). Det er nærliggende å anta at det har sammenheng med det store antallet jaktvåpen $\mathrm{i}$ vårt land.

A Itså har Ibsen beskrevet et selvmord som ved første øyekast synes å skyldes ene og alene en akutt krise. M en han har al likevel beskrevet alle de viktigste risikofaktorer for selvmord i tillegg: trussel om tap av en nær relasjon, mangelfulle nære relasjoner, overdrevet ansvar, psykisk ubalanse, smitte fra familien og lett tilgjengelige selvmordsvåpen. I bsens skuespill fører til samme konklusjon som forskning: Y tterst få selvmord skyldes en enkelt krise alene (G roholt et al. 1998).

\section{Kan kriser ha senvirkninger?}

Vi har mye kunnskap om at livshendelser kan påvirke barns psykiske helse, selv om vi ikke vet hvilke hendelser som fører til hvilke lidelser. H endelsene deles gjerne i fem grupper:

1) Tap (f.eks. dødsfall eller andre brå kontaktbrudd)

2) Problemer i nære relasjoner

3) Store endringer i familien (f.eks. skilsmisser)

4) Hendelser som krever ny sosial tilpasning (f.eks. flytting)

5) A kutte traumatiske hendelser, som ulykker, vold eller katastrofer.

De traumatiske hendel sene har sterk effekt i seg selv, men med trygge omgivelser er barn forbausende godt beskyttet. Barna er mer sårbare når traumene også har i seg noen av de andre kriseaspektene, som tap eller problemer i nære relasjoner, slik fysiske eller seksuelle overgrep innen familien kan ha.

Vanskelige livshendelser kan også øke risikoen for selvmordshandlinger, men først og fremst hvis de skjer sammen med andre faktorer. $M$ ange mener at effekten går via psykologisk dysfunksjon. Vi har f. eks. sett at barn som tar sitt eget liv, oftere enn andre barn har skilte foreldre. M en forskning viser at skilsmisse bare øker selvmordsrisikoen hos unge som er deprimerte eller utagerende ( $G$ roholt et al. 1997). A llikevel er kunnskapen om hvordan tidligere kriser påvirker senere selvmordsatferd mangelfull. Et forskningsprosjekt som er i gang i 0 slo, har dette som tema, og vi må regne med å få klarere kunnskap om denne sammenhengen etter hvert.

\section{Hvilke kriser utløser selvmord?}

Ibsen har intuitivt lagt mange risikofaktorer inn i H edvigs liv før krisen rammer. Som den kloke mann han var, har han intuitivt tegnet et bilde som stemmer med senere forskning. O ftest er det ulykkelige hendelser på toppen av andre sårbarhetsfaktorer som utløser selvmord. En norsk undersøkelse av ungdomsselvmord har vist at omgivelsene oppfatter følgende forhold som van ligste utløsen de hendel se: kjærlighetsbrudd (32\%), forel drekonflikt ( $7 \%$ ), angst for straffereaksjon (13\%), vennekonflikt (4\%) (G roholt et al 1998). For halvparten var ingen utløsen de årsak kjent. I en annen norsk undersøkelse av selvmordsforsøk oppga de unge i gjennomsnitt drøyt fem vanskelige forhold som hadde sammenheng med selvmordsforsøket. Ø verst på listen kom psykiske vansker, så kom problemer i nære relasjoner; til kjæreste, foreldre, venner, eller en somhet. $M$ en også i denne gruppen var det mange som ikke pekte på noen spesiell krisepreget hendelse.

\section{Psykiske lidelser og kriser}

Dette fører oss videre til psykiske lidelser. I alle undersøkelser av ungdomsselvmord har en funnet at den unge hadde en eller annen psykisk lidelse. I U SA, Sverige og Finland fikk over $90 \%$ en psykiatrisk diagnose i ettertid, i N orge noen færre (G roholt et al 1997; Schaffer et al 1996). M en mange av disse lidelsene var ikke erkjent av omgivelsene, og i

$\mathrm{N}$ orge hadde spesielt fă $(24 \%)$ mottatt behandling. Dette er også en lav prosentandel sammenliknet med andre land (Groholt et al 1997).

Depresjon er den lidel sen som sterkest er knyttet til selvmord. A llikevel er bare halvparten av de unge som dør eller skader seg selv, deprimerte. H os unge kan tristheten være overskygget av irritasjon.
D iagnose depresjon settes hvis tilstanden fører til endret vanlig fungering, av minst 2 ukers varighet. Derfor kan vi ikke si at Hedvig var deprimert, selv om hun sikkert var fylt av uendelig fortvilelse da hun skjøt seg. M en vi kan

ikke utelukke at hun lenge hadde vært deprimert, og at leken med ild på kjøkkenet var et uttrykk for fortvilelse. $H$ un var utestengt fra vanlig skole, og ventet forgjeves på hjemmeundervisning fra faren. Selv om hun fulgte hans minste vink, nådde hennes behov aldri opp på hans prioriteringsliste. Bare det kunne vært nok til å utløse en depresjon, især hos en som var disponert på forhånd.

$H$ os voksne er psykoser en viktig årsak til selvmord. Få av de helt unge som tar livet av seg får psykosediagnose, selv om mange psykoser debuterer i ungdomsårene. A llikevel mener jeg at noen av de unge som dør uten en forutgåen de utløsende eller forståelig årsak, kan ha merket de første skremmende tegn på en psykose. M en de har greid å holde symptomene borte fra omgivelsene, især hvis de er ressursrike i utgangspunktet. M ine erfaringer fra samtal er med unge som har forsøkt selvmord, støtter antagelsen. Dette er også i tråd med et viktig funn fra Finland (Kotila 1992): Et sel vmordsforsøk uten påviselig årsak vil statistisk sett oftere etterfølges av selvmord, sammen liknet med forsøk der utløsende årsak er klar. Til slutt må vi også erkjenne at en ubehandlet psykose noen få ganger kan skape så stor psykisk nød at beskyttelse fra foreldre eller andre ikke er nok.

\section{Konklusjon}

Konklusjonen vi må trekke er at akutte kriser ofte er viktig for utløsning av selvmord, men sjelden nok. M en vi må vokte oss vel for å snu på faktorenes orden og si at akutte kriser lett fører til selvmord. Selvmord er en meget sjelden utgang på kriser. Det er sammenfall av mange negative omstendigheter som oftest fører til et selvmord, slik Ibsen viste oss i Vildanden. 
forts. fra forrige side - SU ICID O LO GI 2000, VOL. 5, NR. 1

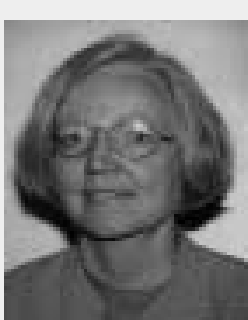

Berit Grøholt er barnepsykiater og har i mange år arbeidet som overlege ved Sentralsykehuset i

A kershus.

De siste årene har hun vært forskningsstipendiat og senere universitetslektor ved Senter for barneog ungdomspsykiatri. Selvmord og selvmordsforsøk hos personer under 20 år har vært fokus i forskningen hennes.

\section{Litteratur}

G jærum B, G røholt B, Sommerschild H. M estring som mulighet i møte med barn, ungdom og foreldre. O slo: TA N O, 1998
G ould M S, Fisher P, Parides M, Flory M, Shaffer $D$. Psychosocial risk factors of child and adolescent completed suicide.

A rch.G en.Psychiatry 1996; 53: 1155-62

G roholt B, Ekeberg 0 , W ichstrom $L, H$ aldorsen $\mathrm{T}$. Youth suicide in N orway, 1990-1992: a comparison between children and adolescents completing suicide and age- and gender-matched controls. Suicide and Life-T hreatening Behavior 1997; 27: 250-263

G roholt B, Ekeberg O, W ichstrom L, $\mathrm{H}$ aldorsen $T$. Suicide among children and younger and older adolescents in N orway: a comparative study [see comments]. Journal of the A merican A cademy of $C$ hild and $A$ dolescent Psychiatry 1998; 37: 473-81
Groholt B, Ekeberg O, W ichstrom L, H aldorsen $T$. Young suicide attempters: A comparison between a clinical and an epidemiological sample. Journal of the A merican A cademy of $C$ hild and A dolescent Psychiatry 2000; In press.

G røholt B. Selvmord, smitteeffekt og massemedia. I: $M$ ehlum $L$, red. Tilbake til livet. Selvmordsforebygging i teori og praksis. K ristiansand: H øyskoleforlaget, 1999:303-17.

Kotila $L$. T he outcome of attempted suicide in adolescence. Journal of $A$ dolescent $\mathrm{H}$ ealth 1992; 13: 415-17

Shaffer D, Gould MS, Fisher P, Trautman P, $M$ oreau $D$, Kleinman $M$, Flory $M$. Psychiatric diagnosis in child and adolescent suicide. A rch.G en.Psychiatry 1996; 53: 339-48 